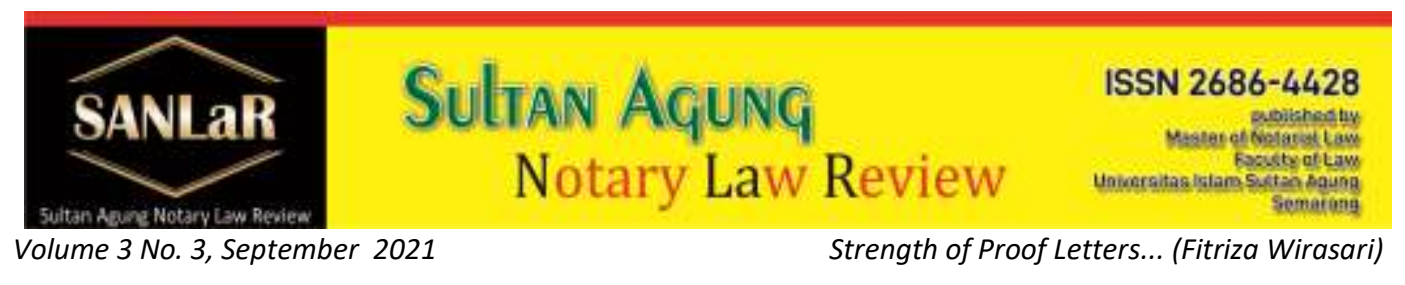

\title{
Strength of Proof Letters Under Hand Legalized by Notaries
}

\author{
Fitriza Wirasari*) \\ *) Faculty of Law, Universitas Islam Sultan Agung (UNISSULA) Semarang, E-mail: \\ fitrizawirasari97@gmail.com
}

\begin{abstract}
The duties and work of a notary as a public official are not limited to making authentic deeds but are also assigned to register and ratify documents under the hand there is legalization from authorized public officials. This study aims to determine the legalization process carried out by a notary, to find out about the responsibility of a notary to legalized underhand letters, to find out how far the power of proof of an underhand letter is as evidence in the trial process in court. This study uses a normative juridical research method. Normative juridical research is research conducted by reviewing applicable laws and regulations or applied to a particular legal problem. Based on the results of the study, it can be seen that the legalization practice carried out by a notary in this case the parties whose names are listed in the letter and affixed their signatures in the letter under the hand can no longer deny that the parties or one of the parties do not know the contents of the letter under the hand, because the contents have been read and explained first before the parties sign before a public official in this case is the notary concerned and in front of the witness. The responsibility of the notary towards the legalized letter under the hand is only limited to the certainty of the date and signature of the parties, that the undersigned in the letter under the hand, it is true that the parties themselves who are in the letter agreement under the hand are not other people. Because the notary must witness first hand and match the identity cards of the parties using the identity card on the day and date on which the letter was made. The legal consequences of proving in court with written evidence, in this case an underhand letter that has been legalized by a notary, have perfect evidentiary power if one of the parties does not deny the signature in the letter, therefore the underhand letter must meet the authenticity requirements determined by the Constitution. If the requirements determined by the law are met, then the legal force of proof becomes the judge's main consideration in making decisions relating to the subject matter being tried in court (Article 1881 paragraph (2) of the Civil Code).
\end{abstract}

Keywords: Proof, Letter; Under Hand; Legalization. 


\section{Introduction}

In the rule of law, human rights must be guaranteed by the state, where every citizen has the same position before the law and the government, this is a consequence of the principle of people's sovereignty and the principle of the rule of law. Certainty, order and legal protection include, among other things, that legal traffic in people's lives is evidence that clearly determines the rights and obligations of a person as a legal subject in society.

Deeds can be divided into two types, namely authentic deeds and underhanded letters. An underhand letter can be made in such a way based on the agreement of the interested parties and the date can be made at any time, while the authentic deed must be made by an authorized official and its form is regulated by law. There are certain officials who are assigned to make records and issue certain deeds regarding a person's civility, such as birth, marriage, death, wills and agreements between the parties where the results or quotations from these records are considered as deeds.

Regarding authentic deeds, it is stated in article 1868 of the Civil Code:

"Authentic deed is a deed (made) in the form determined by law, made by or in the presence of public officials who have the power to do so, at the place where the deed was made."

Officials who are entitled to make authentic deeds are not only Notaries, because what is meant by "authorized public officials" themselves are officials who are indeed given the authority and duty to carry out the registration, for example: KUA officials or civil registry officials in charge of recording marriages, birth and death, PPAT (Land Deed Maker Official) and so on.

In contrast to an authentic deed, an underwritten letter has its own characteristics and characteristics, in the form of:

a. Free form

b. The making does not have to be in front of public officials

c. Still has the power of proof as long as it is not denied by the maker, meaning that the contents of the deed do not need to be proven again unless someone can prove otherwise (deny the contents).

d. In the event that it must be proven, the evidence must also be accompanied by witnesses and other evidence.

Therefore, usually in a private letter, it is better to include two adult witnesses to strengthen the evidence. In practice, private letters are sometimes used for certain personal interests, which are sometimes not the same as the time of manufacture. For example, an underhand letter made today is dated last month and year, because there is no obligation to report an underhand letter, who guarantees that the underhand letter is properly made on time.

The duties and work of a notary as a public official are not limited to making authentic deeds but are also tasked with registering and ratifying private documents, providing legal advice and explanations of the law to the parties 
concerned, making deed of establishment and deed of amendment to a Limited Liability Company and so on. .

An agreement made under the hand is an agreement made by the parties who promise themselves, without a certain standard and only adapted to the needs of the parties. While the strength of the proof is only between the parties if the parties do not deny and acknowledge the existence of the agreement (acknowledging their signature in the agreement made). This means that one of the parties can deny the truth of his signature in the agreement.

It is different with an authentic deed, an authentic deed or commonly called a notary deed has perfect evidentiary power, meaning that it can be used as evidence in court. The purpose of the judicial process is to determine a truth and based on that truth a judge's decision will be determined, to determine a truth in the judicial process a proof is needed. According to Subekti, proving is convincing the judge of the truth of the arguments or arguments put forward in a dispute. ${ }^{1}$

Darwan Prinst stated that what is meant by proof is proof that it is true that a criminal event has occurred and the defendant is guilty of doing it, so he must be held accountable for it. ${ }^{2}$

In Indonesia, some people, especially in rural areas, are still overwhelmed by customs and habits, for important events it is evidenced by testimonies from several witnesses, usually the witnesses for these events are neighbors, friends in the village or the village head. These events can be in the form of ordinary events that are already inherent in the life of the community, such as giving a name to a newborn child, but can also be an event that has important legal consequences, for example in buying and selling or leasing transactions and regarding other important events in the family environment, for example the distribution of inheritance, adoption of children for people who do not have children of their own with the right to inherit. ${ }^{3}$ The agreement usually only uses receipts and stamps as well as the signatures of the parties and without any intermediary public officials. Society in general makes an agreement only based on trust.

An agreement made under the hand is an agreement made by the parties who promise and without any interference from the authorized public employee, and without a certain standard and only adapted to the needs of the parties. The letter under the power of proof is only between the parties. If the parties do not deny and acknowledge their signatures in the agreement, the underwritten letter has perfect power like an authentic deed.

It should be clear that private documents in Article 1874, Article 1874a and Article 1880 of the Civil Code say that every private deed made must be affixed with a dated statement from a notary or other employee appointed by law. Where a notary is a public official who carries out his profession in providing

\footnotetext{
${ }^{1}$ Subekti R, Hukum Pembuktian, print. 13, (Jakarta: Pradnya Paramita, 2001), p. 1.

${ }^{2}$ Prinst Darwan, Hukum Acara Pidana Dalam Praktik, print. 2, (Jakarta: Djambatan, 1998), p. 133.

${ }^{3}$ Notodirejo R Soegondo, Hukum Notariat Di Indonesia, (Jakarta: Rajawali, 1982), p. 4.
} 
legal services to the public, it is necessary to get protection and guarantees in order to achieve legal certainty. However, the reality is that in the daily life of the general public there are still errors regarding underhanded letters and the extent to which the strength of binding underhanded letters in the event of a dispute and the legalization function of underhand letters has an important role to ensure the certainty of the date and signature of the parties ${ }^{4}$.

\section{Research Methods}

This research uses the type of research normative juridical, pthis research reviewing the implementation or implementation positive legal provisions (laws) and factual contracts in every particular legal event that occurs in society in order to achieve the predetermined goals. ${ }^{5}$ The study aims to ascertain whether the results of the application of the legal event in concreto are in accordance with the provisions of the law.

\section{Results and Discussion}

\subsection{The Practice of Making Letters Under Hand Legalized by a Notary.}

An agreement made in writing can be in the form of a deed. In general, the deed is a signed letter, which contains information about events or matters, which are the basis of an agreement. The deed is divided into 2 forms, namely: Authentic Deed and Underhanded Letter. An authentic deed is a deed made by an authorized public official while an underhand letter is a letter made by the parties without an authorized public official intermediary. We already know that an underhand letter is a letter made by the parties concerned by the agreement of the parties without any interference from the authorized public official in this case a notary.

For example, a loan agreement, a lease agreement, receipts and so on. For the manufacture of an underhand letter The existence of witnesses who witnessed the agreement under the hand signed and or affixed with a thumbprint by the parties concerned in the agreement is very important, because its existence will be very meaningful if in the future a problem occurs and or one of the parties denies the contents and provisions contained in the agreement or its signature so that it can be used as a witness in court proceedings. Therefore, the witnesses who witness the existence of an agreement made under the hands of the parties

${ }^{4}$ A Chuasanga, Ong Argo Victoria. (2019). Legal Principles Under Criminal Law in Indonesia Dan Thailand, Jurnal Daulat Hukum, Vol 2, $\quad$ No 1 (2019) http://jurnal.unissula.ac.id/index.php/RH/article/view/4218, see too Deen, Thaufiq., Ong Argo Victoria \& Sumain. (2018). Public Notary Services In Malaysia. JURNAL AKTA: Vol. 5, No. 4, 10171026. Retrieved from http://jurnal.unissula.ac.id/index.php/akta/article/view/4135

${ }^{5}$ Muhammad, Abdulkadir, Hukum dan Penelitian Hukum, Citra Aditya Bakti, Bandung, 2004, p. 134. 
with an interest in their statement can determine whether the agreement is legal or not.

Underhand letters that are legalized by a notary are generally written by the parties concerned with the agreement of both parties, while the signatures and/or thumbprints are executed before a notary. In a private letter made by the parties themselves and their signature or thumbprint before a notary, the responsibility for the contents and provisions contained in the agreement rests with the parties who made it, while the notary's responsibility is only limited to the truth about the signature or the thumbprint and validity of the letter. In the letter under the hand, it is true that the signature or thumbprint of the interested party is based on the identification owned by the parties, one of which is the Identity Card.

Legalization is the ratification of an underhand letter which is read out by a notary and signed by an appearance before a notary at that time to guarantee the certainty of the date of the letter. Where the appearers who include their signatures are known by the notary or introduced to the notary as referred to in Article 15 paragraph 2 letter a of Act No. 2 of 2014 concerning the Position of a Notary, the notary has the authority to ratify the signature and determine the certainty of the date of the letter under the hand, the notary the party signs the agreement under the hand before the Notary so that the Notary can ratify the signature and the date of signing.

Legalization carried out by a notary is a legal act that must meet the following requirements:

a. The signing of the letter under the hand is carried out by the parties before or witnessed by the notary himself.

b. The notary knows the parties who signed the letter under the hand that will be legalized

c. The contents of the underhand letter are explained or explained by a notary to the parties who legalize the underhand letter which is also attended by witnesses.

d. The notary affixes his stamp and signature on the part of the letter under the hand and gives the date according to the date of signing the letter under the hand. After the parties and witnesses put their signatures first.

e. The notary makes a note or statement on the part of the letter under the hand that the notary knows the parties, that the contents of the letter have been read or explained by the parties who appear, that the notary witnessed with his own eyes when the parties signed the letter under the hand.

f. The notary registers the letter under the hand into a special list of legalization books prepared by the notary by the parties who appear. The date when it is signed before a notary is the legal date of the legal action made by the parties which results in obligations between the parties. 


\subsection{The Notary's Responsibility for Proofing Underhanded Letters Legalized by a Notary}

Based on the authority of a Notary to legalize an underhand letter as regulated in Article 15 paragraph (2) of the UUJN, in legalizing an underhand letter, a Notary only matches the signature and determines the date of the underwritten letter. Therefore, there is a legal issue regarding the truth of the legalized underhand letter, whether the notary knows or not the authenticity of the legalized private letter. If the underhand letter contains real truth, then the legalization of the underhand letter by a notary will not cause legal problems in the future. However, if the letter under the hand contains untruths that are not known to the notary, then the legalization of the underhanded letter containing the untruth does not ensnare the notary who legalized it. On the other hand, if the notary knows the untruths contained in the private letter, but in order to get a big profit, the notary conspires with the appearer so that the notary concerned is willing to legalize the underhand letter containing the untruth. In this condition, the legal notary is also involved in legal problems that arise later.

The legal issues raised above occur because the UUJN does not clearly stipulate whether a notary must check the veracity of an underhand letter whose legalization is requested (vague norm). In order for a Notary to avoid legalizing an underhand letter containing untruths or preventing a Notary from conspiring to legalize an underhand letter containing an untruth for personal gain, provisions should be made for the Notary to check the correctness of the contents of the underhand letter to be legalized.

The authority of a notary in legalizing a letter under the hand is of course followed by a person in charge of the action. In connection with the liability of a notary, dependents and confusion regarding the limits of the notary's liability. Based on Article 65 of the Law on Notary Positions, that is, even though all deeds made by a notary, substitute notary, special substitute notary for temporary notary officials have been submitted or transferred to the notary protocol depositary. This is despite having stopped or retired as a notary, he still has to be responsible until he dies.

In relation to the notary's responsibility for legalized documents, it is the certainty of the signature, meaning that the party who signed it was the parties themselves who made the agreement, not someone else. It is said that because the person who legalizes the letter is required to know the person who signed the letter by looking at identification such as Identity Cards and so on. 
With regard to underhand letters legalized by a notary, the notary has full responsibility for 4 (four) matters, namely: ${ }^{6}$

1. Identity of the parties

a. Notaries are obliged to examine the identity of the parties who will sign the letter under the hand in the form of (ID, Passport, SIM) or introduced by another person.

b. Examining whether capable of carrying out legal actions.

c. Examine whether the parties involved signed the letter under the hand.

2. The notary must read the contents of the letter under the hand to the parties and ask whether it is true that the contents of the letter are desired by each party concerned.

3. The signatures of the parties must be affixed in front of a notary directly

4. Putting a date on the letter under the hand is then recorded in a special book register.

Before being returned, each page is numbered and initialed by a notary. Thus, the notary's responsibility for the correctness of the legalized letter under the hand is the signature party, meaning that it is certain that the parties who have signed the letter are the parties themselves, not someone else. It is said so because a notary who legalizes the letter is required to know the person who signed the letter by looking at his identification such as an Identity Card and others. If the notary really knows the parties, then the parties will put their signatures witnessed by the notary on the same day and date.

\subsection{Legal consequences in Proving in Court regarding Underhanded Letters that have been Legalized by a Notary}

Written evidence or written evidence is very important evidence in proving civil cases in court. Evidence is a tool used to prove the truth of the legal relationship stated, both by the plaintiff and by the defendant and to convince the judge before the court. In civil proceedings, judges are concerned with valid evidence, which means that judges can only make decisions based on evidence determined by law.

The evidence in civil proceedings mentioned by law (Article 164 HIR, Article 284 $\mathrm{RBg}$, and Article $1866 \mathrm{Bw}$ ) are:

a. Written evidence

b. Witness evidence

c. Evidence evidence

d. Oath

Written evidence or letters are regulated in Articles 138.165-167 HIR/164, 285305 RBG and Articles 1867-1894 of the Civil Code. Written evidence is the main

${ }^{6}$ Interview with Nurma Ningsih, SH.,MK.n Demak district notary on July 29, 2021 
evidence in civil procedural law compared to other evidence. Because in civil law what is sought is formal truth, the documentary evidence is deliberately made to be used as evidence in the future.

Written evidence or letters are anything that contains reading signs that can be understood and contain a certain thought. The reading signs are meant for example Latin letters, Arabic letters, and so on. Thus, everything that does not contain reading signs, or even though it contains reading signs but cannot be understood, is not included in the meaning of written or letter evidence. ${ }^{7}$

The strength of deed proof is divided into three types, namely: ${ }^{8}$

1. The power of proof is born (third party).

What is meant by the power of proof of birth from a deed is the strength of proof of a letter based on the circumstances of birth, that a letter that looks like a deed is accepted/considered like a deed and treated as a deed, as long as the opposite is not proven. So the letter is treated like a deed, except that the inauthenticity of the deed can be proven by another party, for example, it can be proven that the signature in the deed was falsified. Thus, it means that the proof is based on reality.

2. The power of formal proof

What is meant by formal proof of a deed is a strength of proof based on whether or not the statement he signed in the deed has explained that the signatories of the deed have explained what is contained in the deed. For example, between $A$ and $B$, who make a sale and purchase, acknowledge that the signature stated in the deed is correct, so it is an acknowledgment regarding the statement of the occurrence of the event itself, not regarding the contents of the statement or in this case regarding the statement, "is there really a statement by the parties who signed it". Thus, it means that the proof is based on habits in society, that the person signs a letter to explain that the things listed above are his/her statement.

3. Material proving power

What is meant by material proof of the deed is a strength of proof based on whether or not the contents of the statement signed in the deed, that the legal events stated in the deed have actually occurred, thus provide certainty about the material of the deed. For example, A and B admit that a sale and purchase (legal event) has occurred.

Deed is the most important written evidence in civil cases. A form of letter that is signed and contains information regarding events or matters that are the basis of an agreement. An underhand letter is basically a letter made by the parties for a particular interest or purpose without involving the authorized official. So in a private letter, the letter is enough to be made by the parties themselves and then signed by the parties, for example a receipt, a debt agreement, etc., the

\footnotetext{
${ }^{7}$ Moh. Taufik Makarao, Pokok-pokok Hukum Acara Perdata, (Jakarta Penerbit Rineka Cipta, 2009), p. 99

${ }^{8}$ Ibid p. 48
} 
absence of an authorized official is the main difference between an underhand letter with an authentic deed.

Regarding the strength of proof of private letters, it is necessary to pay close attention to the regulations contained in the 1867 ordinance no. 29 which contains "stipulations on the strength of proof from underhanded writings from Indonesian people or equivalent to them". This ordinance is a deed. While underhand letters are letters that are made by the parties concerned themselves upon the agreement of the parties without any interference from authorized public officials.

Written evidence in the form of a deed is distinguished between an authentic deed and an underhand letter. In the trial, if what is submitted as evidence is only in the form of an underhand letter, the strength of the proof is limited, so that other evidence is still being sought to support it so that evidence is deemed sufficient to reach the truth according to law. So the letter under the hand can be accepted as the beginning of written evidence (Article 1871 of the Civil Code) but according to the article it is not explained what is meant by written evidence. Article 1902 of the Civil Code states the conditions if there is written evidence, namely:

a. There must be a deed

b. The deed must be made by the person against whom the claim is made or from the person he represents.

c. The deed must allow the truth of the event in question

So a letter under the hand to be able to be perfect and complete evidence from the beginning of the written evidence must still be equipped with other evidence. Therefore it is said that the letter under the hand is written evidence. Letters as written evidence are divided into two, namely letters which are deed and other documents which are not deed, while the deed itself is further divided into authentic deeds and private letters. Deed is a signed letter, which contains events that form the basis of a right or engagement, which was made from the beginning intentionally for proof. So to be classified as a deed, the letter must be signed.

The necessity of signing a letter to be called a deed is evident from Article 1869 of the Civil Code, where if the deed is made by an incompetent or incompetent person or the deed is defective, then it is not an authentic deed but has the power to be written under the hand if it is signed by the parties. Thus, train tickets, or so on are not included in the deed.

\section{Closing}

The practice of legalization carried out by a notary in this case the parties whose names are listed in the letter and put their signatures in the letter under the hand can no longer deny that the parties or one of the parties do not know the contents of the letter under the hand, because the contents have been read out 
and explained in advance before the parties affix signatures before a public official in this case is the notary concerned and in front of witnesses. The notary's responsibility for the legalized letter is only limited to the certainty of the date and signature of the parties, that those who have signed the underhand letter are indeed the parties themselves who are in the underhand letter agreement, not someone else. Because the notary must witness firsthand and match the identity cards of the parties using the identity card on the day and date on which the letter was made. The legal consequences in proving in court, written evidence, in this case an underhand letter that has been legalized by a notary, has perfect evidentiary power if one of the parties does not deny the signature in the letter, therefore the underwritten letter must meet the authenticity requirements determined by law. If the requirements determined by the law are met, the legal strength of the evidence becomes the judge's main consideration in making decisions relating to the subject matter of the case being tried in court.

\section{References}

Journals:

[1] A Chuasanga, Ong Argo Victoria. (2019). Legal Principles Under Criminal Law in Indonesia Dan Thailand, Jurnal Daulat Hukum, Vol 2, No 1 (2019) http://jurnal.unissula.ac.id/index.php/RH/article/view/4218

[2] Deen, Thaufiq., Ong Argo Victoria \& Sumain. (2018). Public Notary Services In Malaysia. JURNAL AKTA: Vol. 5, No. 4, 1017-1026. Retrieved from http://jurnal.unissula.ac.id/index.php/akta/article/view/4135

Books:

[1] Moh. Taufik Makarao, Pokok-pokok Hukum Acara Perdata, (Jakarta Penerbit Rineka Cipta, 2009),

[2] Muhammad, Abdulkadir, Hukum dan Penelitian Hukum, Citra Aditya Bakti, Bandung, 2004,

[3] Notodirejo R Soegondo, Hukum Notariat Di Indonesia, (Jakarta: Rajawali, 1982),

[4] Prinst Darwan, Hukum Acara Pidana Dalam Praktik, print. 2, (Jakarta: Djambatan, 1998),

[5] Subekti R, Hukum Pembuktian, print. 13, (Jakarta: Pradnya Paramita, 2001)

Interview:

Interview with Nurma Ningsih, SH.,MK.n Demak district notary on July 29, 2021 